\title{
Reproduction of Angola free-tailed bats (Tadarida condylura) and little free-tailed bats (Tadarida pumila) in Malawi (Central Africa) and elsewhere in Africa
}

\author{
D. C. D. Happold and M. Happold \\ Department of Zoology, Australian National University, Canberra, A.C.T. 2601, Australia
}

\begin{abstract}
Summary. Angola free-tailed bats and little free-tailed bats occur in diverse habitats throughout most of Africa south of the Sahara. This study investigated the reproductive strategies and related biology of these species in Malawi where they were sympatric, and analysed data from elsewhere in Africa to show how the strategies varied along a gradient of habitats from approximately $12^{\circ} \mathrm{N}$ to $25^{\circ} \mathrm{S}$.

Both the Angola free-tailed bat and the little free-tailed bat were normally monotocous. Angola free-tailed bats invariably had 2 births/year, and the interval between consecutive births decreased with increasing latitude. When the interval was shortest ( $~ 90$ days) a post-partum oestrus occurred. Little free-tailed bats differed by having a shorter gestation ( $\sim 60$ days), and the ability to have up to 5 births/year with a postpartum oestrus after each birth. The extent to which this potential is achieved varies with latitude and rainfall, mainly so that lactation can coincide with peaks in the abundance of food. The interaction between rainfall and reproductive characteristics results in the two species having patterns of reproduction which are sometimes similar, but more often different. Competition between the species is unlikely to be affected by differences in their reproduction.
\end{abstract}

Keywords: reproduction; free-tailed bats; Tadarida; Chiroptera; Malawi; Africa

\section{Introduction}

Thirty-one (31) species of molossid bats are known to occur in Africa south of the Sahara (Hayman \& Hill, 1971). Two species, the Angola free-tailed bat, Tadarida (Mops) condylura (A. Smith 1833) and the little free-tailed bat, Tadarida (Chaerephon) pumila (Cretzschmar 1830 or 1831) have broad habitat tolerances, and geographical ranges which are among the most extensive recorded for African microchiropterans. Both occur throughout most of Africa south of the Sahara. They exploit clearings in the rain-forest zones of West and central Africa, woodland savannas both north and south of the equator, and the Angola free-tailed bat also occurs in the Somali arid zone (Verschuren, 1957; Rosevear, 1965; Kingdon, 1974; Rautenbach, 1978; Smithers, 1983; Happold, 1987). Within Malawi, both species are common in suitable habitats in all of the main geographical areas and biotic communities except montane habitats on the high plateaux (Happold et al., 1987). The Angola free-tailed bat and the little free-tailed bat have been recorded sympatrically at specified localities in countries as diverse as Nigeria (Happold, 1987), Uganda (Mutere, 1973), Kenya (O'Shea \& Vaughan, 1980), Malawi (Happold et al., 1987) and South Africa (Pienaar et al., 1980). In Malawi, they have been recorded sympatrically at 7 localities (Happold et al., 1987), and at 3 of these, at least, the 2 species roosted and foraged together.

Angola free-tailed bats and little free-tailed bats forage above the trees, in gaps between trees and in clearings, usually high above the ground (O'Shea \& Vaughan, 1980; this study). Both are opportunistic feeders and eat beetles, moths, bugs, winged termites and cockroaches (Marshall \& 
Corbet, 1959; Kingdon, 1974; Whitaker \& Mumford, 1978) and little free-tailed bats also feed on midges and mosquitoes (Marshall \& Corbet, 1959). The Angola free-tailed bat (forearm $43 \cdot 5-$ $50.0 \mathrm{~mm}$ ) is substantially larger than the little free-tailed bat (forearm $36.0 .42 .0 \mathrm{~mm}$ ) (Happold et al., 1987) and can eat insects with hard integuments whereas the little free-tailed bat is restricted to insects with soft integuments (Lang \& Chapin, 1917; Freeman, 1981). Consequently, when Angola free-tailed bats and little free-tailed bats forage in the same microhabitat, they are likely to compete minimally for food. Both species roost in the hollow trunks and branches of trees, and in buildings (Verschuren, 1957; Rosevear, 1965; Mutere, 1973; Smithers, 1983). Both species have been found singly, in groups of 5-20, and in colonies of several hundred individuals (Verschuren, 1957; Kock, 1969; Smithers, 1971; Kingdon, 1974; Smithers \& Wilson, 1979). Adult males, females and young roost together (Marshall \& Corbet, 1959; Mutere, 1973; this study). At the localities where Angola free-tailed bats and little free-tailed bats were found in this study, hollow trees and/ or suitable buildings were so abundant that domiciles were unlikely to be a limiting factor for either species. Captive Angola free-tailed bats and little free-tailed bats in Malawi became torpid during the day at $21-24^{\circ} \mathrm{C}$, but they are not known to hibernate (Happold \& Happold, 1988).

Because of their extensive distribution, broad habitat tolerance and sympatry, Angola freetailed bats and little free-tailed bats lend themselves to a study of reproduction aimed at (1) comparing the strategies of related species at localities where they occur sympatrically, and (2) assessing and comparing changes in strategy along a gradient of habitats from the equator to temperate latitudes.

To achieve the first objective, we investigated the reproductive strategies of the Angola freetailed bat at Lengwe National Park (with supplementary data from Liwonde N. P. and Cape Maclear), and the little free-tailed bat at Zomba (with supplementary data from Lengwe N. P. and Liwonde N. P.). The species were sympatric at all these localities. Events in the reproductive cycles were related to seasonal changes in rainfall and temperature, and to seasonal changes in the availability of food (assessed qualitatively).

To assess geographical variation in the reproductive strategies, the data from Malawi were compared with data for the Angola free-tailed bat in Uganda (Mutere, 1973) and Kenya (O'Shea \& Vaughan, 1980), and for the little free-tailed bat in Ghana (McWilliam, 1976), Uganda (Marshall \& Corbet, 1959; Mutere, 1973), Kenya (O’Shea \& Vaughan, 1980), Zambia (Ansell, 1986) and South Africa (van der Merwe et al., 1986, 1987). Information about the reproduction of Angola freetailed bats and little free-tailed bats in other parts of Africa is meagre, but has been incorporated to give the clearest picture currently possible of the reproductive strategies of the two species throughout their ranges and along a gradient of habitats from approximately $12^{\circ} \mathrm{N}$ to $25^{\circ} \mathrm{S}$.

\section{Study areas and methods}

Malawi is located in Central Africa, from $9^{\circ} 50^{\prime} \mathrm{S}$ to $17^{\circ} 00^{\prime} \mathrm{S}$, and from $33^{\circ} 00^{\prime} \mathrm{E}$ to $36^{\circ} 00^{\prime} \mathrm{E}$. It lies in the southern savanna biotic zone as defined by Davis (1962). A brief description of the dominant physiographical features of this country and its vegetation is given in Happold et al. (1987) and further details by Pike \& Rimmington (1965) and Jackson (1969).

Malawi has a hot season from November to early April, a cool dry season from April to July, and a hot dry season from August to November. The duration of each season varies with latitude. The mean annual rainfall is $775-2164 \mathrm{~mm}$, depending on locality, with most of the rain falling between November and March. Throughout most of Malawi, the rainfall is unimodal. Temperatures range from extremely hot in the Shire Valley to cool on the high plateaux. Further information on the climate of Malawi is given by Pike \& Rimmington (1965), Torrance (1972) and Malawi Government (1982).

Four localities were investigated during this study. These localities (see also Happold et al., 1987), and the investigations carried out at each, are as follows. 
Lengwe National Park $\left(16^{\circ} 13^{\prime} \mathrm{S}, 34^{\circ} 46^{\prime} \mathrm{E} ; 100 \mathrm{~m}\right)$ in the Lower Shire Valley. The climate is semiarid (for rainfall see Fig. 1c), and the vegetation includes riverine forest, thicket, and thicket-clump savanna (Hall-Martin, 1972; Sherry \& Ridgeway, 1984). Colonies of Angola free-tailed bats roosted under the corrugated iron roof of the toilet block near the visitors' chalets, and under the corrugated iron roof of a mud-brick house at the Scout Camp. The toilet-block colony was sampled monthly from September 1984 to June 1985 (excluding May), and the Scout Camp colony was sampled monthly from November 1984 to June 1985 (excluding May). Little free-tailed bats also roosted (in very small numbers) in the roof of the toilet block, in the walls of the chalets, and in roofs of some of the houses in the Scout Camp. They were caught occasionally, in small numbers, during sampling of the colonies of Angola free-tailed bats.

Liwonde National Park $\left(15^{\circ} 02^{\prime} \mathrm{S}, 35^{\circ} 15^{\prime} \mathrm{E} ; 500 \mathrm{~m}\right)$ in the Upper Shire Valley. The vegetation includes mopane woodland (Colophospernum mopane), mixed deciduous woodland, reed swamps and flood-plain grass savanna (Dudley \& Stead, 1976). Colonies of little free-tailed bats roosting intermittently under the corrugated iron roofs of houses at the Administration Camp were sampled monthly (when present) from September 1984 to June 1985 (excluding May).

Zomba $\left(15^{\circ} 23^{\prime} \mathrm{S}, 35^{\circ} 19^{\prime} \mathrm{E} ; 800-900 \mathrm{~m}\right)$ at the base of Zomba Plateau in the Shire Highlands. This small town has traditional and colonial-style buildings in a mosaic of ornamental gardens, maize and vegetable gardens, groves of bananas, plantations of exotic Eucalyptus, riverine forest, and Brachystegia woodland. The rainfall pattern is given in Fig. 2(d). A colony of little free-tailed bats, roosting under the corrugated iron roof of a colonial-style house, was sampled monthly from October 1984 to June 1985.

Cape Maclear in Lake Malawi National Park $\left(14^{\circ} 02^{\prime} \mathrm{S}, 34^{\circ} 50^{\prime} \mathrm{E} ; 500 \mathrm{~m}\right)$. Cape Maclear is a peninsula of rocky hills projecting into the southern part of Lake Malawi. The hills are covered by Brachystegia woodland. Large numbers of Angola free-tailed bats flying from the roof of a building near the lake were netted on 11 November. Two specimens of the little free-tailed bat were captured in the roof of another building.

Examinations of Angola free-tailed bats were carried out at Lengwe N. P. (225M, 87F) and Lake Malawi N. P. (15M, 28F), and examinations of little free-tailed bats were carried out at Zomba (37M, 112F), Liwonde N. P. (14M, 11F), Lengwe N. P. (15M, 2F) and Lake Malawi N. P. (1M, 1F). Additional data were obtained from the records associated with 17 Angola free-tailed bats and 9 little free-tailed bats in the collection of the Museum of Malawi, Blantyre.

The bats were caught in mist-nets set across flight-paths from domiciles. To minimize disturbance to the colonies, nets were usually set for only 1 night per month. On some occasions, bats were counted as they emerged. The Angola free-tailed bats were examined next morning and then most were released at the site of capture. The little free-tailed bats were usually examined $2-3 \mathrm{~h}$ after capture, and then most were released at the site of capture. Little free-tailed bats from the colony at Zomba were individually identified by using a combination of ear-clipping with diagrams of the natural pattern of white markings on the ventral surface. Some specimens of each species were retained for autopsy and as voucher specimens, some of which are now lodged at the British Museum (Natural History) in London. The bats were weighed to the nearest $0.5 \mathrm{~g}$, and measured to the nearest $0.5 \mathrm{~mm}$. For details and results see Happold et al. (1987). Reproductive condition was assessed by abdominal palpation, examination of the nipples and external genitalia, and/or by autopsy. Two reproductive states were recognized in adult male bats: testes were scrotal or abdominal. Six reproductive states were recognized in adult females: inactive, pregnant, lactating, lactating and pregnant, post-lactating, and post-lactating and pregnant. Females classified as 'inactive' were not detectably pregnant, lactating or recently lactating: they may have been in anoestrus or they may have had embryos in a state of delayed implantation, delayed development or early development. Females classified as 'lactating' were producing milk and were not detectably pregnant but may have been in the very early stages of pregnancy. Females classified as 'postlactating' had enlarged nipples surrounded by a rim of bare skin: they were not detectably pregnant 
but may have been in the early stages of pregnancy. The crown-rump length of fetuses was measured to the nearest $1 \mathrm{~mm}$ both when females were autopsied or palpated. Young bats, including juveniles (not weaned) and subadults (weaned), were distinguished from adults by the colour of their pelage, and by the condition of the phalangeal epiphyses which were knobby, pale and incompletely fused. One pregnant little free-tailed bat and two pregnant Angola free-tailed bats were kept in captivity until they gave birth. The neonates of the Angola free-tailed bats died, but the little free-tailed bat reared her young which was weighed, measured and observed at intervals of 2 days until weaned. Some observations of mother-young behaviour were recorded.

\section{Results}

\section{Reproduction and related biology of Angola free-tailed bats in Malawi}

Size and composition of colonies. The Angola free-tailed bat at Lengwe N. P. and Lake Malawi N. P. roosted in colonies of $18->200$ individuals. Throughout most of the year, samples of the Angola free-tailed bat from Lengwe N. P. contained more males than females (Table 1). The ratio of the total number of males to females was $2 \cdot 6: 1(n=312)$.

Table 1. Reproductive condition and mean weights of Angola free-tailed bats (Tadarida condylura) collected from the Lengwe N. P. between September 1984 and June 1985 (excluding May)

\begin{tabular}{|c|c|c|c|c|c|c|c|c|c|}
\hline & \multicolumn{9}{|c|}{ No. of individuals } \\
\hline & $\begin{array}{c}25 \\
\text { Sep. }\end{array}$ & $\begin{array}{c}22 \\
\text { Oct. }\end{array}$ & $\begin{array}{l}\text { 19-20 } \\
\text { Nov. }\end{array}$ & $\begin{array}{c}\text { 16-17 } \\
\text { Dec. }\end{array}$ & $\begin{array}{c}14-16 \\
\text { Jan. }\end{array}$ & $\begin{array}{c}11 \\
\text { Feb. }\end{array}$ & $\begin{array}{l}10-11 \\
\text { Mar. }\end{array}$ & $\begin{array}{c}11-12 \\
\text { Apr. }\end{array}$ & $\begin{array}{c}11-12 \\
\text { Jun. }\end{array}$ \\
\hline \multicolumn{10}{|c|}{ Reproductive condition* } \\
\hline Males 1 & 8 & 0 & 7 & 2 & 0 & 0 & 1 & 2 & 24 \\
\hline 2 & 2 & 0 & 0 & 0 & 0 & 0 & 0 & 11 & 0 \\
\hline 3 & 3 & 19 & 16 & 20 & 22 & 9 & 26 & 0 & 0 \\
\hline Females 1 & 1 & 0 & 2 & 1 & I & 0 & 0 & 0 & 0 \\
\hline 2 & $6^{a}$ & $7^{b}$ & 1 & $1^{\mathrm{c}}$ & 1 & 0 & 0 & 0 & 0 \\
\hline 3 & 0 & 0 & 0 & 8 & 0 & 0 & 7 & 4 & 0 \\
\hline 4 & 0 & 0 & 0 & 0 & 1 & 0 & 0 & 0 & 0 \\
\hline 5 & 0 & 0 & 0 & 0 & $5^{\mathrm{d}}$ & $6^{e}$ & 2 & 0 & 0 \\
\hline 6 & 0 & 0 & 0 & 12 & 3 & 0 & 2 & 1 & I \\
\hline \multicolumn{10}{|l|}{ Total } \\
\hline Adult males & 13 & 19 & 23 & 22 & 22 & 9 & 27 & 13 & 24 \\
\hline Adult females & 7 & 7 & 3 & 22 & 11 & 6 & 11 & 5 & 1 \\
\hline Young males & 0 & 0 & 0 & 2 & 15 & 2 & 2 & 12 & 20 \\
\hline Young females & 0 & 0 & 0 & 0 & 3 & 0 & 0 & 7 & 2 \\
\hline \multicolumn{10}{|l|}{ Mean weight (g) } \\
\hline Adult males & $20 \cdot 0$ & $23 \cdot 4$ & $26 \cdot 4$ & $28 \cdot 3$ & $29 \cdot 3$ & $27 \cdot 1$ & $26 \cdot 7$ & $25 \cdot 6$ & $26 \cdot 5$ \\
\hline Adult females & $20 \cdot 5$ & $20 \cdot 6$ & $24 \cdot 2$ & $24 \cdot I$ & $25 \cdot 9$ & $28 \cdot 7$ & $23 \cdot 6$ & $20 \cdot 9$ & $20 \cdot 0$ \\
\hline
\end{tabular}

*For adult males, 1 = testes abdominal; $2=$ testes scrotal, $<6 \mathrm{~mm} ; 3$ = testes scrotal, $6-9 \mathrm{~mm}$. For adult females, $1=$ reproductively inactive; 2 = pregnant but not lactating or post-lactating; 3 = lactating but not perceptibly pregnant by palpation; $4=$ lactating and pregnant; $5=$ post-lactating and pregnant; $6=$ post-lactating but not perceptibly pregnant. $\mathrm{CR}=$ crown-rump lengths of fetuses in pregnant females: $a=C R 3-8 \mathrm{~mm}(6$ autopsied); $b=C R$ 16$19 \mathrm{~mm}$ ( 2 autopsied, 5 palpated); $=$ CR $20 \mathrm{~mm}$ ( 1 autopsied); $\mathrm{d}=\mathrm{CR} 12-13 \mathrm{~mm}$ ( 2 autopsied, 1 palpated); e = CR $25 \mathrm{~mm}$ (1 autopsied).

Diet, and the availability of food in relation to rainfall. In captivity, the Angola free-tailed bat ate winged termites (Macrotermes sp.), beetles up to $15 \mathrm{~mm}$ long, and moths. No other kinds of insects were offered. At Lengwe N. P. the abundance of different insects varied from month to month, as assessed qualitatively. Flying insects were conspicuously more abundant during the wet season; in April and June, and from September to November, flying insects of all kinds were relatively scarce. 
Table 2. Reproductive condition and mean weights of little free-tailed bats (Tadarida pumila) collected from Zomba between October 1984 and June 1985

\begin{tabular}{|c|c|c|c|c|c|c|c|c|c|}
\hline & \multicolumn{9}{|c|}{ No. of individuals } \\
\hline & $\begin{array}{c}27 \\
\text { Oct. }\end{array}$ & $\begin{array}{c}24 \\
\text { Nov. }\end{array}$ & $\begin{array}{c}27 \\
\text { Dec. }\end{array}$ & $\begin{array}{c}25 \\
\text { Jan. }\end{array}$ & $\begin{array}{c}24 \\
\text { Feb. }\end{array}$ & $\begin{array}{l}\text { 30-31 } \\
\text { Mar. }\end{array}$ & $\begin{array}{c}15 \\
\text { Apr. }\end{array}$ & $\begin{array}{c}16 \\
\text { May }\end{array}$ & $\begin{array}{c}15 \\
\text { Jun. }\end{array}$ \\
\hline \multicolumn{10}{|c|}{ Reproductive condition* } \\
\hline Males 1 & 1 & 1 & 3 & 2 & 0 & 1 & 1 & 0 & 4 \\
\hline 2 & 2 & 3 & 1 & 0 & 0 & 0 & 0 & 0 & 0 \\
\hline Females 1 & 1 & 0 & 1 & 0 & 0 & 0 & 0 & 0 & 0 \\
\hline 2 & $13^{\mathrm{a}}$ & $10^{\mathrm{b}}$ & 0 & 0 & 0 & 0 & 0 & 0 & 0 \\
\hline 3 & 0 & 0 & 8 & 0 & 3 & 3 & 5 & 0 & 0 \\
\hline 4 & 0 & 0 & 0 & 0 & 0 & 0 & 0 & 0 & 0 \\
\hline 5 & 0 & 0 & 0 & $7^{\mathfrak{c}}$ & 4 & 0 & 0 & $1^{d}$ & 0 \\
\hline 6 & 0 & 0 & 0 & 0 & 2 & 7 & 3 & 3 & 2 \\
\hline \multicolumn{10}{|l|}{ Total } \\
\hline Adult males & 3 & 4 & 4 & 2 & 0 & 1 & 1 & 0 & 4 \\
\hline Adult females & 14 & 10 & 9 & 7 & 9 & 10 & 8 & 4 & 5 \\
\hline Young males & 0 & 0 & 0 & 2 & 2 & 3 & 2 & 0 & 11 \\
\hline Young females & 0 & 0 & 0 & 1 & 2 & 11 & 9 & 7 & 8 \\
\hline \multicolumn{10}{|l|}{ Mean weight (g) } \\
\hline Adult males & $9 \cdot 3$ & $11 \cdot 3$ & 11.5 & $10 \cdot 5$ & - & $10 \cdot 0$ & $9 \cdot 5$ & - & $10 \cdot 4$ \\
\hline Adult females & $10 \cdot 2$ & $14 \cdot 3$ & $11 \cdot 8$ & $12 \cdot 1$ & - & $9 \cdot 8$ & $9 \cdot 6$ & $10 \cdot 1$ & $10 \cdot 5$ \\
\hline
\end{tabular}

Table 3. The reproductive condition of recaptured females of Tadarida pumila from the colony at Zomba

\begin{tabular}{|c|c|c|c|c|c|c|c|c|c|c|}
\hline \multirow[b]{2}{*}{ Age* } & \multirow[b]{2}{*}{$\begin{array}{c}\text { Field } \\
\text { no. }\end{array}$} & \multirow[b]{2}{*}{ Cohort } & \multicolumn{8}{|c|}{ Reproductive condition $\dagger$} \\
\hline & & & $\begin{array}{c}27 \\
\text { Oct. }\end{array}$ & $\begin{array}{c}24 \\
\text { Nov. }\end{array}$ & $\begin{array}{c}27 \\
\text { Dec. }\end{array}$ & $\begin{array}{c}25 \\
\text { Jan. }\end{array}$ & $\begin{array}{c}24 \\
\text { Feb. }\end{array}$ & $\begin{array}{l}30-31 \\
\text { Mar. }\end{array}$ & $\begin{array}{c}15 \\
\text { Apr. }\end{array}$ & $\begin{array}{c}15 \\
\text { Jun. }\end{array}$ \\
\hline A & 105 & - & 2 & & 3 & & & & & \\
\hline A & 106 & - & 2 & 2 & 3 & & & & & \\
\hline A & 107 & - & 2 & & & & 6 & 6 & & \\
\hline A & 119 & - & 2 & & 3 & 5 & 5 & & & \\
\hline A & 550 & - & & 2 & 3 & & & & & \\
\hline A & 563 & - & & 2 & 3 & 5 & & & & \\
\hline A & 569 & - & & & 3 & 5 & & & & \\
\hline A & 800 & - & & 2 & & 5 & & & & \\
\hline A & 917 & - & & & & & 3 & 3 & 3 & \\
\hline $\mathrm{Y}$ & 804 & 1 & & & & 1 & 1 & & & 1 \\
\hline $\mathrm{Y}$ & 918 & 1 & & & & & 1 & & 1 & \\
\hline $\mathrm{Y}$ & 1088 & ? & & & & & & 1 & 1 & \\
\hline $\mathrm{Y}$ & 1094 & i & & & & & & 1 & & 1 \\
\hline Y & 1202 & 2 & & & & & & & 1 & 1 \\
\hline
\end{tabular}

${ }^{*} \mathrm{~A}=$ adult $\mathrm{Y}=$ young.

$\dagger 1=$ reproductively inactive; $2=$ pregnant but not lactating or post-lactating; $3=$ lactating but not perceptibly pregnant; $4=$ lactating and pregnant; $5=$ post-lactating and pregnant; $6=$ post-lactating but not perceptibly pregnant. 

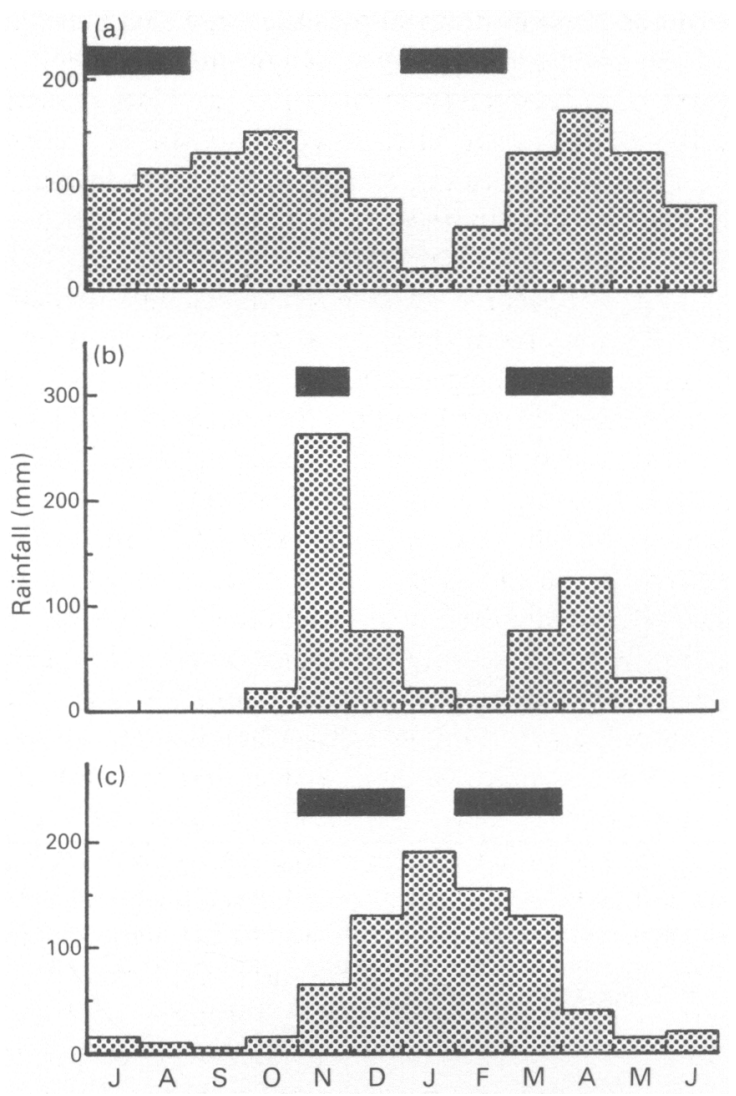

Fig. 1. Mean monthly rainfall, and periods of parturition (black bars) for Angola free-tailed bats (Tadarida condylura) in diverse parts of their geographic range. (a) Uganda, Bukalasa (Mutere, 1973). (b) Kenya, Masalina (T. J. O'Shea, personal communication; O'Shea \& Vaughan, 1980). (c) Malawi, Lengwe N. P. (Malawi Government, 1982; this study). The rainfall data for Malawi are for Chikwawa, which is the nearest meteorological station to Lengwe N. P. In Uganda and Kenya, bats were collected in every month of the year. At Lengwe N. P. in Malawi, bats were collected from September to June (excluding May), but the samples of adult females in November and June were small $(<5)$. Periods of parturition in all studies were derived from observations of pregnancy (assessed only by abdominal palpation or gross autopsy).

Litter size. Thirty-four pregnant females examined by palpation or autopsy each contained 1 fetus. In the 18 autopsied females, the fetus was implanted in the right horn of the bicornuate uterus.

Female reproductive chronology. The reproductive conditions of adult females from the colonies at Lengwe N. P. are given in Table 1. A sequence of reproductive events (i.e. pregnancy without signs of recent lactation, pregnancy with simultaneous lactation, pregnancy with signs of recent lactation, and lactation without pregnancy), indicated that females had two consecutive litters during one breeding season, and that there was a post-partum oestrus. Post-partum oestrus has not previously been recorded in this species. In September, and to a lesser extent in October, the variation recorded in the crown-rump lengths of embryos showed that although all the females were pregnant, they were not in close reproductive synchrony. The maximum crown-rump length recorded was $32.5 \mathrm{~mm}$. This fetus had its eyes open and teeth erupted and was evidently at the end of 
term. From the observation that crown-rump lengths at Lengwe N.P. ranged from 16 to $19 \mathrm{~mm}$ on 22 October, and that a heavily pregnant female was caught on 19 November, it was concluded that the first cohort of young was born between early November and late December. Two females taken from Lengwe N. P. on 16 January, gave birth in captivity on 15 February and 25 March. In conjunction with the data from females examined in the field from January to April, this indicates that the second cohort of young was born between early February and late March. The two births in captivity showed that females were out of synchrony by as much as $\mathbf{4 0}$ days during their second pregnancy. Young, weighing 16-21 g, some with the remains of milk in their faeces, were mistnetted in December, January and February (cohort 1) and in April (cohort 2).

Two observations, taken together, suggest that the gestation is about 90 days: (a) the interval between the estimated first births of cohort I and the first births of cohort 2 was about 90 days; and (b) a female which was conspicuously pregnant when caught, gave birth in captivity 68 days later. The duration of lactation could not be determined in this study.

The percentage of females which were pregnant was $100 \%$ in October and February. This indicates that it is normal for females to have 2 litters in each breeding season, and that females probably breed in the season following their birth, when they are 6-9 months old.

At Lengwe N. P., births occurred during the wet season (Fig. 1c). The highest percentages of lactating females were recorded in December (when the rainfall was very heavy and flying termites and beetles were very abundant), and in March-April (when the rainfall was tailing off and beetles, termites and moths were relatively scarce although midges and mosquitoes were abundant).

Elsewhere in Malawi, reproductive data for Angola free-tailed bat females are very limited. At Cape Maclear on 11 November, 39\% females were pregnant, $18 \%$ were lactating, $29 \%$ were postlactating, and $14 \%$ were inactive $(\mathrm{N}=28)$. Evidently this colony started breeding earlier than the colony at Lengwe N. P. In the northern region of Malawi, pregnant females were found on 16 December 1960 (near Mzuzu) and 25 May 1961 (Karonga) (records at Museum of Malawi, Blantyre). The wet season at Karonga extends from November to May (Malawi Government, 1982) and is therefore 2 months longer than the wet season at Lengwe N. P.

Male reproductive chronology. Observations on the position of testes (Table 1) suggest that testes of most males became scrotal in August-September, reached maximum size $(9 \times 4 \mathrm{~mm})$ in September-October, and became abdominal in March. This spans the time from the conception of the first cohort of young in August to the birth of the second cohort in February-March. However, it was not possible (in this study) to correlate the position of the testes with spermatogenesis or fertility, and until this has been investigated, the data cannot be fully interpreted. In November, $33 \%$ of the males still had abdominal testes. These males weighed $22.0-26.0 \mathrm{~g}$ (mean $23.9 \mathrm{~g}$ ), whereas the males with scrotal testes weighed $26 \cdot 5-29.5 \mathrm{~g}$ (mean $27.9 \mathrm{~g}$ ). This suggests that the males with abdominal testes were either young, or in poor condition. If it is shown that scrotal testes indicate spermatogenesis, then the high percentage of males with scrotal testes in December $(91 \%)$ and January $(100 \%)$ indicates that males reach reproductive maturity about half way through the breeding season following their birth, when they are 9-12 months old.

Ontogeny. Two Angola free-tailed bats were born in captivity. The smallest had sucked, indicating that the births were not premature. Measurements $(\mathrm{mm})$ were forearm $25 \cdot 0,27 \cdot 5$; total length 70,75 ; weight $(\mathrm{g}): 5 \cdot 4,7 \cdot 5$. The weight of the larger neonate was $32 \%$ of the mean weight of nonpregnant adult females, and its total length was $70 \%$ of the mean total length of adult females. The neonates were naked and darkly pigmented on the dorsal surface. The ear pinnae were free, the auditory meatus and eyes were open, and the deciduous teeth had erupted. The thumbs $(9 \mathrm{~mm})$ and hindfeet were adult-sized, and the tactile hairs on the toes and soles of the feet were well-developed.

Two juveniles born with the November-December cohort at Lengwe N. P. were netted in midDecember when they were estimated to be $\sim 1$ month old. Measurements were: forearm 47 , $47.5 \mathrm{~mm}$; weight $16.0,16.0 \mathrm{~g}$. The forearms of 14 juveniles in January were $44.5-48.0 \mathrm{~mm}$ (mean $46.8 \mathrm{~mm}$ ) and their weights were $17.0-23.0 \mathrm{~g}$ (mean $19 \cdot 2 \mathrm{~g}$ ). Some had the remains of both milk and insects in their faeces. The epiphyses of the wings were still enlarged and the pelage was darker, not 
flecked, shorter and more velvety than in adults. These observations show that juveniles reach adult size, but not adult weight, within 1-2 months, and before they are completely weaned.

\section{Reproduction and related biology of little free-tailed bats in Malawi}

Size and composition of colonies. The colony studied at Zomba comprised $20-30$ adults throughout the study period, but the composition was considerably labile. The samples of volant bats contained many more females than males, except in June (Table 2). The ratio of the total number of adult males to females caught at this colony was $1: 3 \cdot 7(\mathrm{~N}=71)$. The ratio of the total number of young males to young females was $1: 1 \cdot 6(\mathrm{~N}=51)$.

Diet, and the availability of food in relation to rainfall. In captivity, the little free-tailed bat ate winged termites (Macrotermes sp.), small moths, cockroaches, small beetles and small grasshoppers. No other kinds of insects were offered. The abundance of flying insects at Zomba increased conspicuously during the wet season, but no quantitative data are available.

Litter size. Twenty-three (23) pregnant females from Zomba, Liwonde N. P. and Lengwe N. P. each contained 1 fetus. In 6 autopsied females, the fetus was implanted in the right horn of the bicornuate uterus: in one female, implantation was in the left horn.

Female reproductive chronology. The reproductive conditions of adult females from the colony at Zomba are given in Tables 2 and 3. These data indicate that females have a post-partum oestrus (as shown histologically by Harrison (1958) and van der Merwe et al. (1987)) and at least 2, often 3, and sometimes 4 consecutive litters during one breeding season. All females examined on 24 November were very close to parturition, and it is assumed that they would have given birth during the last week of November. The data suggest that a second cohort of young is born at the end of January, a third cohort at the end of March and a fourth cohort at the end of May. Volant subadults with weights from $7 \cdot 0$ to $8.5 \mathrm{~g}$ were captured on 25 January (cohort 1), 30-31 March and 15 April (cohort 2) and 15 June (cohort 3).

The interval between successive births appears to be about 60 days. The females which gave birth at the end of November were still lactating about 4 weeks later. Some of the females which gave birth at the end of January were still lactating 3-4 weeks later, but some appeared to have just stopped lactating. In captivity, one female lactated for 48 days, but the development of her offspring was abnormal (see below) and therefore the duration of lactation may have been abnormal also. These data suggest that the length of lactation is flexible, but lasts for at least 3-4 weeks.

At Zomba, the first 3 consecutive litters were born during the wet season, but the 4th litter (which appeared to be a very rare event) was born early in the cool dry season (Fig. 2d). During the wet season, flying insects were conspicuously more abundant. Of the females which gave birth in November, $100 \%(\mathrm{~N}=7(\mathrm{Jan})$.$) had a second litter in January. However, only about 44 \%(\mathrm{~N}=9$ (Feb.), $\mathrm{N}=10$ (Mar.)) of the females had a litter in March, and probably very few had a litter in May (Table 2). These data suggest that only about $80 \%$ of the full reproductive potential of the little free-tailed bat in the wet season ( 3 births/female) was realized.

The reproductive condition of 5 marked young which were recaptured (Table 3 ) indicates that females (including those from cohort 1) did not breed in the season of their birth. In OctoberNovember, $90-100 \%$ of the females were pregnant, which suggests that most young females breed in the breeding season following their birth, when they are 6-10 months old.

Data from Liwonde N. P. and Lengwe N. P., although limited, were consistent with those from Zomba. At Cape Maclear, one female was post-lactating at the end of November, suggesting that births occurred earlier here than at other localities. At Cape Maclear, comparatively early births were also recorded for the Angola free-tailed bat.

Male reproductive chronology. Since very few males were examined, the observations on the position of testes in males from Zomba (Table 2), and elsewhere in Malawi, are inconclusive.

Ontogeny and the behaviour of mother and young. One fetus, near end of term on 24 November, had a crown-rump length of $24.5 \mathrm{~mm}$ and a forearm measurement of $13 \mathrm{~mm}$. The skin was un- 
pigmented except on the muzzle, ears, elbow, hindfeet and tail. The eyes and auditory meatus were open, the pinnae were free, and the deciduous teeth were just showing.

On Day 1, the neonate born in captivity had a forearm of $22.5 \mathrm{~mm}$ and was $3.5 \mathrm{~g}$ in weight. The weight of the neonate was $33 \%$ of the mean weight of non-pregnant adult females, and its total length was $56 \%$ of the mean total length of adult females. The neonate was naked except for long tactile hairs on the rump and hind-feet, as in adults. The dorsal surface was black with pigmentation and the ventral surface was pink. The eyes and auditory meatus were open, the pinnae were free, and the deciduous teeth were fully erupted. Growth was very rapid. Fur concealed the dorsal and ventral skin by Day 6. By Day 22, the total length, head, tibia, hindfoot and weight had reached the range recorded in adults. The forearm and tail reached $32.5 \mathrm{~mm}$ and $25 \mathrm{~mm}$ by Day 38 , but did not grow longer and did not reach the range recorded in adults. The juvenile was not able to fly by the time it was weaned, and therefore the development of his wings and tail is considered abnormal. In contrast, volant juveniles of weight $7-9 \mathrm{~g}$ and forearm $36.5-39 \mathrm{~mm}$ were netted from the Zomba colony in January, which indicated that both adult weight and size were normally attained within 1-2 months after birth.

On Day 1, the neonate was able to scuttle forwards and backwards, and climb up and down vertical surfaces. Foreign objects were sniffed. The pinnae twitched in response to squeaks made by the observer, and the neonate twitched in response to being lightly touched. The neonate climbed onto the mother's back, and was carried when she moved in the vicinity of the roost. Except when the neonate was sucking, mother and young roosted side by side, head down against the vertical sides of a crevice between two bricks. During the night, the mother left the neonate in the crevice while she foraged and fed.

By Day 6, scuttling and climbing were adult-like in speed and agility. The juvenile groomed himself and exhibited all elements of adult grooming behaviour. The mother was not observed to groom the juvenile. From Day 6 to Day 50 (when observations were terminated), the juvenile explored the vicinity of the roost, but was not seen to move into the open area of the cage, and did not accompany the female when she left the roost to forage and feed. The juvenile sniffed, nudged and climbed-over the mother, and pushed-under in order to suck. In contrast, maternal behaviour appeared to be limited to returning to the juvenile, allowing him to roost on her back or against her side, and suckling. The juvenile did not remain attached to the nipple unless sucking, and did not remain attached when the mother moved. (Similarly, no females with young attached were mistnetted in the field.) Mother-young interactions included several vocalizations which were audible to the observers. The bats vocalized when they were separated from each other, and when they regained physical contact.

The juvenile began to eat insects on Day 44, and was not observed to suck after Day 48. Because the wings and tail of the captive juvenile did not develop normally, observations were curtailed on Day 50 .

\section{Geographical variation in the reproduction of Angola free-tailed bats}

The reproduction of Angola free-tailed bats has been followed for at least 1 year at two localities.

(1) Uganda, Bukalasa $\left(0^{\circ} 43^{\prime} \mathrm{N}\right)$ (Mutere, 1973). This locality is in the rainforest zone. Rain falls throughout the year with peaks of heavy rain extending from August to November and from March to May (Fig. la). Pregnancies were recorded from December to February and from May to July and young were born in February-March and in July-August just before each period of peak rainfall (Fig. 1a). This cycle of events was observed for 2 consecutive years. It was assumed that each female had 2 litters per year. The number of moths caught in a Malaise trap at Makerere ( $50 \mathrm{~km}$ from Bukalasa) was greatest during the periods of peak rainfall.

(2) Kenya, Masalani (2॰18'S) (O'Shea \& Vaughan, 1980). The vegetation here is woodland savanna and the rainfall is bimodal (Fig. 1b). Births occurred in November and in March-April. 
Although both pregnancy and lactation were investigated, the simultaneous occurrence of pregnancy and lactation was not observed. At Diani, Kenya $\left(4^{\circ} 15^{\prime} \mathrm{S}\right)$, the number of insects caught in a light trap was closely correlated with rainfall (McWilliam, 1982, in Racey, 1982).

Data from other parts of the geographic range of this bat are limited to casual observations in 1-2 months of the year, and no conclusions about reproductive cycles are possible. In Mauritania $\left(16^{\circ} 31^{\prime} \mathrm{N}\right), 6$ females $(83 \%)$ were pregnant in April (Qumseyeh \& Schlitter, 1981). In Zaïre ( $3^{\circ} 40^{\prime}-$ $4^{\circ} 40^{\prime} \mathrm{N}$ ), females were not pregnant or lactating in March but some were pregnant in April and May (Verschuren, 1957). At another locality in Zaïre $\left(1-2^{\circ} \mathrm{N}\right)$, juveniles were present in October, but not in January or April (Verschuren, 1966). In Zambia $\left(12^{\circ} 00^{\prime}-13^{\circ} 00^{\prime} \mathrm{S}\right)$, pregnant females were found in January, and juveniles in February (Ansell, 1960). In Botswana $\left(18^{\circ} 00^{\prime} \mathrm{S}\right)$, pregnant females were found in January (Smithers, 1971, 1983), and in South Africa $\left(22^{\circ} 20^{\prime}-25^{\circ} 31^{\prime}\right.$ S $)$ "young were recorded during summer months" (Pienaar et al., 1980). The data from Zambia, Botswana and South Africa are consistent with the data from Malawi.

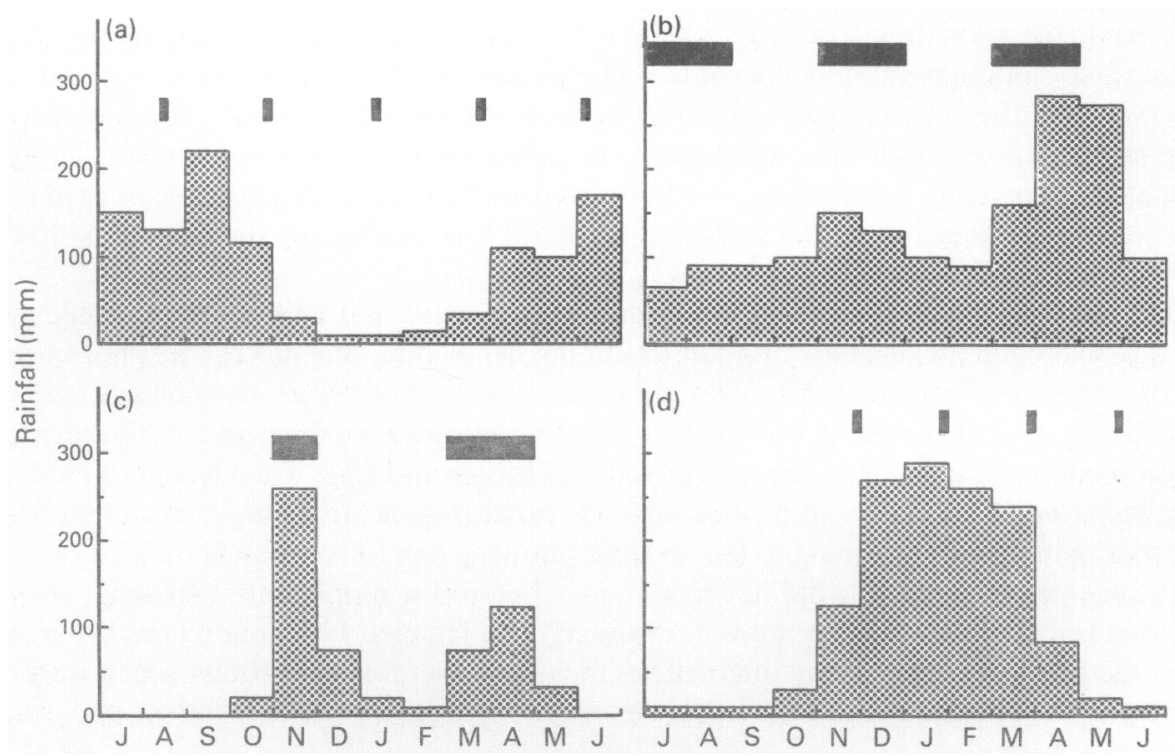

Fig. 2. Mean monthly rainfall, and estimated peak periods of parturition (black bars) for little free-tailed bats (Tadarida pumila) in diverse parts of their geographic range. (a) Ghana, Mole N. P. (McWilliam, 1976). (b) Uganda, Entebbe (our interpretation of data in Mutere, 1973). (c) Kenya, Masalina (T. J. O'Shea, personal communication; O'Shea \& Vaughan, 1980). (d) Malawi, Zomba (Malawi Government, 1982; this study). In Uganda and Kenya, bats were collected in every month of the year. In Ghana, bats collected from July to September provided evidence of 3 periods of parturition during the wet season, and a single bat (pregnant and lactating) collected in January provided evidence of 2 parturitions during the dry season. In Malawi, bats were collected from October to June, but the sample of adult females in May was small $(<5)$. Periods of parturition in all studies were derived from observations of pregnancy (assessed only by abdominal palpation or gross autopsy).

\section{Geographical variation in the reproduction of little free-tailed bats}

The information on the reproductive chronologies of this bat in diverse parts of its range can be summarized as follows. 
(1) Ghana, Mole N.P. $\left(9^{\circ} 11^{\prime}\right.$ to $\left.10^{\circ} 06^{\prime} \mathrm{N}\right)(\mathrm{McWilliam}, 1976)$. The vegetation is Guinea woodland savanna and the wet season is April-October with peaks in June and September (Fig. 2a). McWilliam (1976) found that at least $93 \%$ of females gave birth to 3 litters during the wet season, and there was evidence (from 1 female) of continued cyclicity with 2 births during the dry season (Fig. 2a). The proportion of females achieving the maximum of 5 births/year was not determined. Births were markedly synchronized during the wet season, with peaks in early June and midAugust. Births also occurred in October, January and at the end of March, but the exact dates were not ascertained. The timing of the wet season births was the same in 2 consecutive years. The gestation was found to be 67-72 days. The young became volant at about 19 days of age, attained adult proportions and weight about 2 months later, and some (males and females) became reproductively mature in just under 3 months.

(2) Sudan, four localities from $12^{\circ} 31^{\prime}$ to $14^{\circ} 24^{\prime} \mathrm{N}$ (Kock, 1969). Wet season occurs with unimodal rainfall in June-October. Nine (9) females collected in March-April were not pregnant or lactating; naked young were found in June, and in October $72 \%$ of 32 females were pregnant, and immature bats were present. The pregnant females, unlike those described by Harrison (1958) in Nigeria and Somalia, "showed no evidence of a second breeding season". This probably means that the pregnant females were not also lactating. Kock's (1969) data show that young are born at the beginning of June and at the end of October. McWilliam (1976) suggested that the immature bats in the October sample could have been born in June, or in August, which would indicate that the reproductive cycles of the little free-tailed bat in the Sudan and Ghana were similar. Kock (1969) noted that the neonates found in June were born just before the wet season, and that when the rains started there was an immediate increase in swarming insects.

(3) Niger, Parc National $W\left(11^{\circ} 54^{\prime}-12^{\circ} 35^{\prime} \mathrm{N}\right)$ (Poché, 1975). In this Sahel savanna vegetation, the wet season occurs with unimodal rainfall in May-September. A pregnant female was obtained in May.

(4) Nigeria, Maiduguri $\left(12^{\circ} 0^{\prime} \mathrm{N}\right)$ (Harrison, 1958). The wet season with unimodal rainfall is May-September (Happold, 1987). One female was pregnant and lactating in May.

(5) Burkino Faso (Upper Volta), Noberé $\left(11^{\circ} 26^{\prime} \mathrm{N}\right)$ (Koopman et al., 1978). The wet season with unimodal rainfall is May-September. One female was pregnant on 30 August.

(6) Somalia, Margherita (not located) (Harrison, 1958). One female was pregnant and lactating in May.

(7) Uganda, Jinja $\left(0^{\circ} 26^{\prime} \mathrm{N}\right)$ (Marshall \& Corbet, 1959). In this rainforest zone, there is rain throughout the year with a small peak in October and November and a larger peak in April and May. In one colony, pregnancies were recorded in all months, but the percentage of females pregnant ranged from 7 to $63 \%$. These authors concluded that "within the general pattern of continuous breeding within the colony, groups of females were in reproductive synchronization", and that the high ratio of pregnancies suggested that females were polyoestrous.

(8) Uganda, Entebbe $\left(0^{\circ} 6^{\prime} \mathrm{N}\right)$ (Mutere, 1973). In this rainforest zone, rain occurs throughout the year with a small peak in November and December and a larger peak in April and May (Fig. 2b). Pregnancies were recorded in all months (range 14-87\%). More than $80 \%$ of the females were pregnant in November, January and June. Mutere (1973) did not observe simultaneous pregnancy and lactation in any individual. He concluded that reproduction in little free-tailed bats at Entebbe was aseasonal, with peaks coinciding with peaks in rainfall, and that, unlike the Angola free-tailed bats, the females were monoestrous. With polyoestry in mind, the Ugandan data, especially that of Mutere (1973), can be reanalysed and reinterpreted. The data from Mutere (1973, his Fig. 1) can be analysed to show that the percentage of heavily pregnant females (weights $10-15 \mathrm{~g}$ ) fluctuates from 9 to $71 \%$, with peaks occurring in October $(71 \%)$, February $(53 \%)$ and June-July $(87 \%, 70 \%)$. Each of these peaks is followed by an abrupt drop, i.e. November-December-January $41 \rightarrow 12 \rightarrow 9 \%$, March-April-May $40 \rightarrow 43 \rightarrow 27 \%$ and August-September $23 \rightarrow 14 \%$. In conjunction with the observation that groups of females were in reproductive synchronization (Marshall \& Corbet, 1959), this suggests that many (although not all) of the reproductively mature females give 
birth during three discrete seasons of parturition: November-December, March-April and JulyAugust (Fig. 2b). If polyoestry is assumed, these data also suggest that females have 3 births/year at intervals of 4 months. The simultaneous occurrence of pregnancy with lactation would not be expected if this was so, and in fact, was not observed. Marshall \& Corbet (1959, their Fig. 1) graphed falls in percentage pregnancy in October-November, March-April and July-August: the timing of these falls suggests that many of the births occur in 3 discrete periods at Jinja as well as Entebbe.

(9) Kenya, Masalani ( $\left.2^{\circ} 18^{\prime} \mathrm{S}\right)$ (O'Shea \& Vaughan, 1980). Vegetation and climate given above. Births occurred in November, and in March-April (Fig. 2c). The simultaneous occurrence of pregnancy and lactation was not recorded.

(10) Zambia, Ngoma $\left(15^{\circ} 54^{\prime} \mathrm{S}\right)$ (Ansell, 1986). This is woodland savanna vegetation with the wet season unimodal November to April (Ansell, 1978). Pregnancies without lactation were recorded on 22 September 1967, 2 November 1966, 14 December 1966, and 7 February 1967. Pregnancies with lactation or recent lactation were recorded on 14 December 1966, 7 February 1967 and 10 March 1967. On 15 April 1967, females were not pregnant or recently lactating. Ansell (1986) suggested that females probably gave birth in early November, again in late December and a third time in February-March. This implies an interval of about 60 days between consecutive births. Ansell (1986) observed that most females had 2 consecutive litters, but only some had a 3rd litter, during the one breeding season.

(11) Moçambique, Kasumbadedza (16 $\left.07^{\prime} \mathrm{S}\right)$ (Lawrence \& Loveridge, 1953). The wet season has unimodal rainfall November-March. On 25 January, 3 females had large embryos at the end of term.

(12) Zimbabwe, Triangle $\left(21^{\circ} 0^{\prime} \mathrm{S}\right)$ (Smithers \& Wilson, 1979). The wet season has unimodal rainfall November-March. Pregnant females were taken in April.

(13) Botswana, Kisane $\left(17^{\circ} 45^{\prime} \mathrm{S}\right)$ (Smithers, 1971). The wet season has unimodal rainfall November-March. Pregnant females were recorded October-February (and one in August). Many hairless young were seen in November and February.

(14) Republic of South Africa, Kruger N. P. $\left(24^{\circ} 59^{\prime}\right.$ S) (van der Merwe et al., 1986, 1987). The wet season here has unimodal rainfall October-March. From late April to late July, females showed no signs of reproductive activity. Pregnancies were recorded for 8 months of the year (August-April). Females had a post-partum oestrus, and were apparently able to bear 3 consecutive litters. The gestation period, determined from the interval between the earliest conception and the first subsequent appearance of a full-term fetus, was $\sim 60$ days. The majority of females ovulated and conceived in close synchrony during the first half of September. There were two subsequent peaks in ovulation/conception during the second half of November and the first half of February. Synchronization was less pronounced during these peaks. It was assumed that there was no variation in the gestation period, and that therefore births occurred in 3 peaks, the first in early November, the second in late January and the third in early April. Lactation lasted at least 30 days, and females became sexually mature in the following breeding season.

\section{Discussion}

Although large numbers of bats were examined during this study, the monthly samples of adult females were sometimes small, and they were obtained from a limited number of collecting sites. However, it is assumed throughout this paper that the samples were representative of the entire populations of each species. This assumption is supported by two observations. Firstly, the skewed sex ratios recorded in this study are similar to those recorded by Verschuren $(1966,1980,1982)$, Mutere (1969) and Smithers (1971), suggesting that the compositions of the colonies investigated in this study are not unusual. Secondly, there appears to be no evidence of segregation (on the basis of sex, reproductive condition, age or social status) in the populations investigated by Marshall 
\& Corbet (1959), Mutere (1969) and Smithers (1971), although Verschuren (1957) raised the possibility of temporary segregation of the sexes in some populations in Zaïre.

Females of the Angola free-tailed bat with single fetuses have been recorded in Mauritania (Qumseyeh \& Schlitter, 1981), Niger (Poché, 1975), Zaïre (Verschuren, 1957, 1966), Uganda (Mutere, 1973), Kenya (O'Shea \& Vaughan, 1980), Zambia (Ansell, 1960) and Botswana (Smithers, 1971). "Young (1-2) have been recorded during the summer months" at Kruger N. P. in South Africa (Pienaar et al., 1980) but this cannot be taken as evidence of twin births. Females of the little free-tailed bat with single fetuses have been recorded in Ghana (McWilliam, 1976), Niger (Poché, 1975), Zaïre (Verschuren, 1957), Uganda (Marshall \& Corbet, 1959), Kenya (O'Shea \& Vaughan, 1980), Zambia (Ansell, 1986), Zimbabwe (Smithers \& Wilson, 1979), Botswana (Smithers, 1971) and South Africa (van der Merwe et al., 1986). McWilliam (1976) found 1 female in Ghana with an embryo in each horn. These data suggest that Angola free-tailed bats and little free-tailed bats (except extremely rarely) are monotocous throughout their geographic ranges. In this they resemble most molossids (Carter, 1970), and the only exception in Africa appears to be the midas free-tailed bat (Tadarida midas) (Verschuren, 1957; Pienaar et al., 1980).

In Angola free-tailed bats, implantation was invariably in the right horn of the uterus. The restriction of functional activity to the right ovary and right uterine horn appears to be the norm for females of all Tadarida so far investigated, with the exception of $T$. midas (Smithers, 1971). Implantation in the right horn is evidently also the norm for the little free-tailed bat, but 2 records of implantation in the left horn (McWilliam, 1976; this study) show that the left ovary is not always atrophic in this species.

Mutere (1973) suggested that the gestation of Angola free-tailed bats in Uganda was about 2 months. At Lengwe N. P. the interval between the 2 births, and the evidence of a post-partum oestrus, implied that the gestation was about 90 days, and further evidence for a gestation exceeding 2 months in Malawi came from the female which was conspicuously pregnant when caught and gave birth 68 days later. If Mutere's (1973) estimation is correct, this implies that the gestation in Malawi is longer than in Uganda. In little free-tailed bats, the interval between the births of consecutive cohorts of young in Malawi was calculated to be about 60 days, which agrees with the gestation in South Africa (van der Merwe et al., 1986), but is 8-12 days shorter than in Ghana (McWilliam, 1976). Lactation in Malawi was at least 3-4 weeks, and similar to that in South Africa (van der Merwe et al., 1987).

Angola free-tailed bats and little free-tailed bats are opportunistic feeders, and can adapt their diets to take advantage of changes in the relative abundance of different kinds of insects as the wet season progresses. Consequently, polyoestry is a viable strategy for these species. In Malawi, polyoestry appears to be uncommon in microchiropterans: it occurs in females of the Mauritian tomb-bat (Taphozous mauritianus) but females of 6 other species for which data are available are monoestrous (D. C. D. Happold \& M. Happold, unpublished).

Angola free-tailed bats and little free-tailed bats have precocious young. The weights of the neonates, in relation to the weights of adult non-pregnant females $(32-33 \%)$, are slightly above the range $(15-\sim 30 \%)$ recorded for other chiropterans (Orr, 1970). The total length of the neonates in relation to the total length of adult females (56-70\%) lies within the range $42-72 \%$ recorded in 6 other species of bats (Sherman, 1930; Kulzer, 1958; Tamsitt \& Valdivieso, 1965; Jones, 1967). In the neonates of both species, the eyes and auditory meatus are open and the ears are functioning. This contrasts with neonates of most species of bats in which the pinnae hang down and cover the auditory meatus, and the eyes are closed (Orr, 1970; Hill \& Smith, 1984).

Mutere (1973) postulated that Angola free-tailed bats reach reproductive maturity in the breeding season after birth. If this were so, reproductive maturity in Uganda is reached in 4-5 months, whereas in Malawi it takes 6-9 months. Marshall \& Corbet (1959) and Mutere (1973) postulated that little free-tailed bats in Uganda reached reproductive maturity rapidly, and this was confirmed in Ghana by McWilliam (1976) who found that some females bred when they were less than 3 months old. In contrast, in Malawi (this study) and South Africa (van der Merwe et al., 1986), little 
free-tailed bat females did not breed until the wet season after their birth, when they were at least 5-6 months old.

In Malawi, the Angola free-tailed bat and the little free-tailed bat differ in their annual reproductive potential. Both species breed in the breeding season following their birth and both are monotocous, but whereas most females of the Angola free-tailed bat have 2 births/year, females of the little free-tailed bat have 2,3 or 4 births/year. There is no evidence that this discrepancy results in the little free-tailed bat being more abundant than the Angola free-tailed bat. In fact, the relative numbers of the Angola free-tailed bat and the little free-tailed bat in the collections of bats from most localities in Malawi where the species are sympatric (Happold et al., 1987) suggest that the Angola free-tailed bat may be more abundant than the little free-tailed bat.

Because there is no evidence that females of the Angola free-tailed bat have more than 2 births/ year (even in Uganda where conditions are most likely to favour more than 2 births/year), it seems that the colonies at Lengwe N. P. come close to achieving the maximum reproductive potential possible for the species, with about $90 \%(\mathrm{~N}=39)$ of the captured adult females being detectably pregnant before the period of births in November-December, and $88 \%(\mathrm{~N}=33)$ being detectably pregnant before the period of births in February-March. Similarly, in Uganda, $80-90 \%$ of the females were pregnant before the period of births in December and January (Mutere, 1973).

It is evident that, in savanna habitats with unimodal wet seasons, the maximum reproductive potential of the little free-tailed bat during the wet season is 3 births/female and that the annual potential (based on continuous polyoestry during the dry season) would be 5 births/female. The colony at Zomba achieved only about $80 \%$ of its potential in the wet season because only about $44 \%$ of the females had a 3rd litter, and its annual potential was far from fulfilled because apparently very few females had a 4th litter, and there was no evidence of a 5 th period of parturition. The achievement of the little free-tailed bat in South Africa (van der Merwe et al., 1986) is similar, for the same reasons. In contrast, the little free-tailed bat in Ghana achieved almost complete fulfilment of reproductive potential ( 3 births/female) in the wet season, and there is evidence that the additional 2 births did occur during the dry season (McWilliam, 1976). However, the proportion of females having 4 or 5 births/year in Ghana has not been determined.

The timing of events in the reproductive cycles of the Angola free-tailed bat and the little freetailed bat reflects firstly, the desirability of synchronizing the maximum demand for food with the maximum abundance of food, and secondly, the limitations imposed by the length of gestation. The greatest demand for food by the population occurs when the adult females are simultaneously pregnant and lactating, and their young are starting to eat insects. For the Angola free-tailed bat at Lengwe N. P., this situation occurs in December and January which are the months of highest rainfall (Fig. 1c) and maximum abundance of beetles, moths and winged termites. For little freetailed bats at Zomba, periods of peak demand for food occur in December and in February which are also characterized by high rainfall (Fig. 2d) and abundant insects. Because its gestation in Malawi is $80-90$ days, the Angola free-tailed bat cannot have 3 births during the wet season, but it can have 2 births with time to spare, and this may explain the lack of close reproductive synchrony between the females. In contrast, because its gestation is only 60 days, the little free-tailed bat can have 3 births during the wet season, but with little time to spare, which may explain why the females are in close reproductive synchrony.

The correlation between the abundance of flying insects and rainfall was noted qualitatively during this study, and has been documented quantitatively in diverse parts of Africa, including Uganda (Mutere, 1973) and Kenya (McWilliam, 1982, in Racey, 1982) where 2 peaks in insect abundance coincide with the 2 peaks in rainfall.

When the diets and reproductive cycles of the Angola free-tailed bat in Uganda, Kenya and Malawi are compared, it is evident that this species feeds opportunistically and breeds opportunistically to take advantage of the peak(s) in insect abundance, and consequently shows geographic variation in its reproduction. In all 3 localities, the births are timed so that lactation and weaning occur in months of heavy rainfall (Fig. 1). This is achieved by adjusting the interval between 
consecutive births: thus births occur at intervals of 6 months in Uganda, 4-5 months in Kenya, possibly 3-4 months at Karonga in northern Malawi, and 3 months at Lengwe $\mathbf{N}$. P. in southern Malawi (Fig. 1). In Malawi, the interval between consecutive births is approximately equal to the length of gestation, which means that females are simultaneously lactating and pregnant for several weeks after the birth of the first litter. This is energetically expensive, but is the only way the birth of 2 litters can be fitted into the short wet season prevailing at these latitudes. In Kenya, the interval between births enables lactation and weaning to coincide with the peaks in rainfall when insects are up to 28 times more abundant than in the dry season (McWilliam, 1982, in Racey, 1982). However, in Uganda, where there is substantial rainfall throughout the year, and the fluctuation in moths is only 3-fold (Mutere, 1973), it is surprising that the Angola free-tailed bat continues to have only 2 births/year. There is no obvious reason why females do not have a post-partum mating after parturition in February and thereby have a third litter in May. The abundance of moths increases markedly between March and May and moths are also very abundant in June (Mutere, 1973); since Angola free-tailed bats eat moths in Uganda (Mutere, 1973), the failure to have a litter in May does not seem to be due to a scarcity of food.

Extrapolating from the correlation between breeding and rainfall in Malawi, the Angola freetailed bat is predicted to have an austral cycle with 2 consecutive litters born during the short, unimodal wet season which prevails throughout its range in southern Africa. The data from Zambia (Ansell, 1960), Botswana (Smithers, 1971, 1983) and South Africa (Pienaar et al., 1980), although too meagre to be conclusive, are consistent with this prediction. If the same correlation between births and rainfall persists in savannas north of the equator, births will occur in May and August-September. The limited data from Mauritania (83\% females pregnant in April) (Qumseyeh \& Schlitter, 1981) are consistent with a boreal cycle meeting these specifications.

Comparison of the reproductive cycles of the little free-tailed bat in diverse parts of its range shows that this species is also reproductively flexible and able to breed opportunistically. In the southern savannas, the little free-tailed bat has an austral cycle with up to 3 births during the 4-month wet season, as has been documented in Malawi (this study), Zambia (Ansell, 1986) and South Africa (van der Merwe et al., 1986), with consistent data also from Botswana (Smithers, 1971) and Moçambique (Lawrence \& Loveridge, 1953). The little free-tailed bat, like the Angola free-tailed bat, has a boreal reproductive cycle in savannas north of the equator. In Ghana, there are 3 consecutive births in the wet season between May and October and, for at least some females, 2 more births in the intervening dry season (McWilliam, 1976). The data from Niger (Poché, 1975), Burkino Faso (Koopman et al., 1978), Nigeria (Harrison, 1958) and the Sudan (Kock, 1969) are consistent with a boreal cycle with these specifications. In Kenya, the two wet seasons are too short and too far apart for the little free-tailed bat to benefit from post-partum mating. In Uganda, pregnancies have been recorded in all months, but it seems very likely that each female has 3 births per year and that most of the births occur in 3 peaks, the 2 biggest coinciding with the peaks in rainfall in November-December and in April-May. The peak of births in July-August occurs during the driest months, but in Uganda the rainfall is substantial in all months, and it is significant that moths are as abundant in July-August as they are in November-December. In both Kenya and Uganda, the little free-tailed bat avoids the energy-expensive co-incidence of pregnancy and lactation.

In habitats where the Angola free-tailed bat and the little free-tailed bat are sympatric, their patterns of reproduction are sometimes similar, but more often different (Figs $1 \& 2$ ). This is the result of two conspicuous differences in their reproduction. Firstly, the little free-tailed bat has a shorter gestation, and, secondly, it can have at least 3 births without intervening periods of reproductive inactivity whereas the Angola free-tailed bat is only known to have 2. In Kenya, because the two wet seasons are too short and too far apart for the little free-tailed bat to benefit from its short gestation, its reproductive strategy here is similar to that of the Angola free-tailed bat. In Uganda, both species avoid simultaneous pregnancy and lactation, and both give birth during the 2 periods of high rainfall, but the little free-tailed bat also gives birth in the intervening drier period, 
and perhaps breeds with considerably less synchrony between females. In Malawi, the little freetailed bat fits 3 births into the 4-month wet season and sometimes has a 4th birth in the dry season, whereas the Angola free-tailed bat has only 2 births in the wet season. Although in Uganda and Malawi the reproductive strategies of the Angola free-tailed bat and the little free-tailed bat are different, in each of these places there are 2 periods each year when both species are lactating, and this also applies in Kenya where the strategies of the two species are similar. It has been suggested that differences in the reproductive strategies of the Angola free-tailed bat and the little free-tailed bat help to reduce competition between them in Uganda (Mutere, 1973), but the overlap in the periods of lactation suggests that differences in diet, and the abundance of domiciles, are more important than the differences in reproduction in reducing competition.

The combination of dietary and reproductive flexibility is probably one of the main reasons why the Angola free-tailed bat and the little free-tailed bat have such extensive ranges, and why they can thrive in such diverse habitats. Only 9 other species of microchiropterans have ranges that are as extensive, and at least one of these (the banana pipistrelle, Pipistrellus nanus; F. Vespertilionidae) also exemplifies different reproductive strategies in different habitats (Laval \& Laval, 1977).

This study was part of a project on the small mammals of Malawi during an Outside Studies Programme granted to D.C.D.H. from the Australian National University in 1984-1985. We thank the Australian National University for financial support; Chancellor College, University of Malawi, for generous hospitality; the Malawi Department of National Parks and Wildlife for permission to work on mammals in Malawi, and provision of facilities and assistance during our field work in national parks; and David and Isobel Bone who allowed us to study the bats which they enjoyed having in their home and garden.

\section{References}

Ansell, W.F.H. (1960) Mammals of Northern Rhodesia. The Government Printer, Lusaka.

Ansell, W.F.H. (1978) The Mammals of Zambia. The National Parks and Wildlife Service, Chilanga, Zambia.

Ansell, W.F.H. (1986) Some Chiroptera from southcentral Africa. Mammalia 50, 507-519.

Carter, D.C. (1970) Chiropteran reproduction. In About Bats. A Chiropteran Biology Symposium, pp. 233-246. Eds B. H. Slaughter \& D. W. Walton. Southern Methodist University Press, Dallas.

Davis, D.H.S. (1962) Distribution patterns of Southern African Muridae, with notes on some of their fossil antecedents. Ann. Cape Prov. Museums 11, 56-76.

Dudley, C.O. \& Stead, D. (1976) Liwonde National Park. Part 1, An introduction. Nyala 2, 17-28.

Freeman, P.W. (1981) A multivariate study of the family Molossidae (Mammalia, Chiroptera): morphology, ecology, evolution. Fieldiana Zoology 7, 1-173.

Hall-Martin, A.J. (1972) Aspects of the plant ecology of the Lengwe National Park, Malawi. M.Sc. thesis, University of Pretoria.

Happold, D.C.D. (1987) The Mammals of Nigeria, 402 pp. Oxford University Press, Oxford.

Happold, D.C.D. \& Happold, M. (1988) Renal form and function in relation to the ecology of bats (Chiroptera) of Malawi. J. Zool., Lond. 215, 629-655.

Happold, D.C.D., Happold, M. \& Hill J.E. (1987) The bats of Malawi. Mammalia 51, 337-414.
Harrison, D.L. (1958) A note on successive pregnancies in an African bat (Tadarida pumila websteri Dollman). Mammalia 22, 592-594.

Hayman, R.W. \& Hill, J.E. (1971) Order Chiroptera. In The Mammals of Africa. An Identification Manual, pp. 1-73. Eds J. Meester \& H. W. Setzer. Smithsonian Institution Press, Washington.

Hill, J.E. \& Smith, J.D. (1984) Bats: A Natural History, $243 \mathrm{pp}$. British Museum (Natural History), London.

Jackson, G. (1969) The grasslands of Malawi: Part II. Soc. Malawi J. 22, 18-25.

Jones, C. (1967) Growth, development and wing loading in the evening bat, Nycticeus humeralis (Rafinesque). J. Mammal. 48, 1-19.

Kingdon, J. (1974) East African Mammals. An Atlas of Evolution in Africa. IIA (Insectivores and Bats), 341 pp. Academic Press, London.

Kock, D. (1969) Die Fledermaus-Fauna des Sudan (Mammalia, Chiroptera). Abh. senckenberg. naturforsch. Ges. 521, 1-238.

Koopman, K.F., Mumford, R.E. \& Heisterberg, J.F. (1978) Bat records from Upper Volta, West Africa. Am. Mus. Novitates 2643, 1-6.

Kulzer, E. (1958) Untersuchungen über die Biologie von Flughunden der Gattung Rousettus Gray. $Z$. Morphol. Oekol. Tiere 47, 374-402.

Lang, H. \& Chapin, J.P. (1917) Part II. Notes on the distribution and ecology of Central African Chiroptera. Bull. Am. Mus. nat. Hist. 37, 479-496. 
Laval, R.K. \& Laval, M.L. (1977) Reproduction and behaviour of the African banana bat, Pipistrellus nanus. J. Mammal. 58, 403-410.

Lawrence, B. \& Loveridge, A. (1953) Zoological results of a fifth expedition to East Africa. 1. Mammals from Nyasaland and Tete. Bull. Mus. comp. Zool. Harv. $110,1-80$.

Malawi Government (1982) Climatological Tables for Malawi, $76 \mathrm{pp}$. Meteorological Services, Chileka, Malawi.

Marshall, A.J. \& Corbet, P.S. (1959) The breeding biology of equatorial vertebrates. Reproduction of the bat, Chaerephon hindei at latitude $0^{\circ} 26^{\prime} \mathrm{N}$. Proc. zool. Soc. Lond. 132, 607-616.

McWilliam, A.N. (1976) The biology of Tadarida (Chaerephon) pumila (Cretzschmar) and partitioning of food resources among insectivorous bats in northern Ghana. B.Sc. Hons thesis, Zoology Department, University of Aberdeen.

McWilliam, A.N. (1982) Adaptive responses to seasonality in four species of Microchiroptera in coastal Kenya. Ph.D. Thesis, Zoology Department, University of Aberdeen.

Mutere, F.A. (1969) Flight activity of tropical Microchiroptera, Tadarida (Chaerephon) pumila Cretzschmar and Tadarida (Mops) condylura A. Smith. Lynx 10, 53-59.

Mutere, F.A. (1973) Reproduction in two species of equatorial free-tailed bats (Molossidae). East Afr. Wildl. J. 11, 271-280.

Orr, R.T. (1970) Development: prenatal and postnatal. In Biology of Bats, pp. 217-231. Ed. W. A. Wimsatt. Academic Press, New York.

O'Shea, T.J. \& Vaughan, T.A. (1980) Ecological observations on an East African bat community. Mammalia 44, 485-496.

Pienaar, U. de V., Rautenbach, I.L. \& de Graaf, G. (1980) The Small Mammals of the Kruger National Park. ( $A$ Checklist and Atlas), 149 pp. National Parks Board of South Africa.

Pike, J.G. \& Rimmington, G.T. (1965) Malawi: a Geographical Study, 229 pp. Oxford University Press, London.

Poché, R.M. (1975) The bats of National Park W, Niger, Africa. Mammalia 39, 39-50.

Qumseyeh, M.B. \& Schlitter, D.A. (1981) Bat records from Mauritania, Africa (Mammalia: Chiroptera). Ann. Carnegie Mus. 50, 345-351.

Racey, P.A. (1982) Ecology of reproduction. In Ecology of Bats, pp. 57-104. Ed T. H. Kunz. Plenum Press, New York.
Rautenbach, I.L. (1978) A numerical re-appraisal of the Southern African biotic zones. Bull. Carnegie Mus. nat. Hist. 6, 175-187.

Rosevear, D.R. (1965) The Bats of West Africa, $418 \mathrm{pp}$. Trustees of the British Museum (Natural History), London.

Sherman, H.B. (1930) Birth of the young Myotis austroriparius. J. Mammal. 11, 495-503.

Sherry, B.Y. \& Ridgeway, A.J. (1984) A Field Guide to Lengwe National Park. Montfort Press, Limbe.

Smithers, R.H.N. (1971) The mammals of Botswana. Mem. nat. Mus. Rhodesia 4, 1-339.

Smithers, R.H.N. (1983) The Mammals of the Southern African Subregion, 736 pp. University of Pretoria, Pretoria.

Smithers, R.H.N. \& Wilson, V.J. (1979) Check list and atlas of the mammals of Zimbabwe Rhodesia. Mem. nat. Mus. Zimbabwe-Rhodesia 9, 1-193.

Tamsitt, J.R. \& Valdivieso, D. (1965) Reproductive cycle of the big fruit-eating bat Artibeus lituratus palmarum, in Columbia. Carib. J. Sci. 5, 157-166.

Torrance, J.D. (1972) Malawi, Rhodesia and Zambia. In Climates of Africa (World Survey of Climatology Vol. 10), pp. 409-460. Ed. J. F. Griffiths. Elsevier Publishing Co., Amsterdam.

van der Merwe, M., Rautenbach, I.L. \& Van der Colf, W. (1986) Reproduction in females of the little free-tailed bat, Tadarida (Chaerephon) pumila, in the eastern Transvaal lowveld. J. Reprod. Fert. 77, 355-364.

van der Merwe, M., Giddings, S.R. \& Rautenbach, I.L. (1987) Post-partum oestrus in the little free-tailed bat, Tadarida (Chaerephon) pumila (Microchiroptera: Molossidae) at $24^{\circ}$ S. J. Zool., Lond. 213, 317-326.

Verschuren, J. (1957) Ecologie, biologie et systematique des Chiroptères. Explor. Parc Nat. Garamba. Inst. Parcs Nat. Congo Belge 7, 1-473.

Verschuren, J. (1966) Introduction à l'écologie et à la biology des Cheiroptères. Explor. Parc Nat. Albert. Inst. Parcs Nat. Congo 2, 25-65.

Verschuren, J. (1980) Note sur les cheiroptères du Burundi. Bull. Inst. r. Sci. nat. Belg. 52(19), 1-9.

Verschuren, J. (1982) Recherches scientifiques dans les parcs nationaux du Sénégal. XXII. Note sure les cheiroptères du Sénégal, principalement dans les parcs nationaux du Niokolo-Koba et du Delta du Saloum. Mem. Inst. Fondamental D'Afrique Noire, 92, 307-313.

Whitaker, J.O. \& Mumford, R.E. (1978) Foods and ectoparasites of bats from Kenya, East Africa. $J$. Mammal. 59, 632-634.

Received 27 April 1988 